Киселев С.В., Строков А.С., Белугин А.Ю. ${ }^{1}$

\title{
Последствия
}

\section{возможного вступления}

\section{Республики Беларусь в ВТО:}

сценарии для сельского хозяйства

\author{
Проанализировано возможное вступление Республики Беларусь в \\ BTO. С помощью эконометрической модели EPACIS даны оценки \\ последствий для сельского хозяйства и потребительского рынка \\ страны. Представлены результаты сценариев сокращения господ- \\ держки сельского хозяйства Республики Беларусь.
}

Ключевые слова: Беларусь, сельское хозяйство, ВТО, EPACIS, экономико-математическое моделирование.

Продолжается процесс вступления стран в ВТО. В данном контексте для России представляет большой интерес анализ последствий возможного вступления в нее стран-членов Таможенного союза, в том числе Республики Беларусь, одного из важнейших торговых партнеров Российской Федерации. Для анализа использовалась модель EPACIS ${ }^{2}$, а в качестве базового был взят 2012 г.

1 Киселев Сергей Викторович - заведующий Кабедрой агроэкономики Экономического факультета МГУ им. М.В. Ломоносова, доктор экономических наук, профессор; Строков Антон Сергеевич - заведующий отделом экономики Евразийского цеентра по продовольственной безопасности (Аграрный центрр) МГУ им. М.В. Ломоносова, кандидат экономических наук; Белугин Алексей Юрьевич - младиий научный сотрудник Евразийского иентра по продовольственной безопасности (Аграрный центр) МГУ им. М.В. Ломоносова.

2 Модель EPACIS (Economic Policy Analisys for CIS) позволяет подробно анализировать торговые потоки, а также влияние на них экономической политики, в том числе поддержки сельского хозяйства. Это дает возможность наблюдать за изменением сальдо сельскохозяйственной торговли, детально исследовать ситуаиию по каждому продукту или продуктовым группам, используемым в модели. Данная модель является моделью частичного равновесия, была разработана в Германии в Институте аграрного развития в Центральной и Восточной Европе IАМО в конuе 1990-х годов. 
Модель является статической и предназначена для сравнительного анализа экономической политики на агропродовольственном рынке. В данном случае исследовалось влияние поддержки сельского хозяйства, так как предполагается, что при вступлении в ВТО торговые барьеры не изменятся. Республика Беларусь и Республика Казахстан при присоединении к ВТО должны в максимальной степени сохранить существующий таможенно-тарифный режим, действующий в России и во всем Таможенном союзе. С высокой долей вероятности на Республику Беларусь могут быть распространены существующие обязательства России. Однако это остается предметом переговоров по ее вступлению в ВТО.

Господдержка была распределена по трем группам:

- общие меры (general measures), не оказывающие искажающего воздействия на производство и торговлю;

- субсидирование факторов производства (input subsidies), не связанное с поддержкой конкретного продукта;

- прямая поддержка (direct support), «привязанная» к конкретным продуктам.

Подобная группировка в целом эквивалентна классификации, применяемой в Таможенном союзе. В качестве товарных групп были использованы важнейшие 11 видов продукции: пшеница, прочее зерно, масличные, сахар, картофель, овощи, фрукты, молоко, говядина, свинина, мясо птицы. Именно по данным товарным группам была распределена поддержка сельского хозяйства.

Расчет по методологии ВТО ценовой поддержки, поддержки по государственным гарантиям исполнения обязательств сельскохозяйственных производителей, а также бюджетные расходы республиканского бюджета и местных бюджетов Республики Беларусь дали общий объем в 2012 г. около 21 трлн руб., или 2,5 млрд долл. Для сравнения: поддержка сельского хозяйства в Российской Федерации по методологии ВТО составляет, по нашим расчетам, в 2012 г. около 6 млрд долл. При сопоставлении поддержки сельского хозяйства с объемом валовой продукции сельского хозяйства в Беларуси этот показатель составляет $21,6 \%$, а в России всего $7,4 \%$.

При подготовке данных из расчетов были исключены те объемы, которые оказались либо ненужными в модели, либо не соответствующими методологии ВТО. Например, в модели отсутствует лен, поскольку объемы его поддержки незначительны. В результате были получены данные по поддержке сельского хозяйства, представленные в табл. 1. 


\section{Таблииа 1}

\section{Господдержка в Республике Беларусь в 2012 г.,}

долл./ 1 т произведенной продукции

\begin{tabular}{|l|l|l|l|}
\hline $\begin{array}{l}\text { Наименование } \\
\text { продукции }\end{array}$ & $\begin{array}{l}\text { Группа 1 } \\
\text { (общие меры) }\end{array}$ & $\begin{array}{l}\text { Группа 2 } \\
\text { (факторы производства) }\end{array}$ & $\begin{array}{l}\text { Группа 3 } \\
\text { (прямая поддержка) }\end{array}$ \\
\hline Пшеница & 1,15 & 8,19 & 0,00 \\
\hline Прочее зерно & 0,44 & 3,13 & 0,00 \\
\hline Масличные & 0,00 & 0,00 & 0,00 \\
\hline Сахар & 30,66 & 218,24 & 12,51 \\
\hline Овощи & 9,29 & 66,15 & 0,00 \\
\hline Картофель & 1,28 & 9,08 & 4,78 \\
\hline Фрукты & 9,32 & 66,36 & 0,00 \\
\hline Молоко & 23,02 & 163,82 & 9,05 \\
\hline Говядина & 79,43 & 565,32 & 4,70 \\
\hline Свинина & 48,93 & 348,24 & 0,00 \\
\hline Мясо птицы & 104,24 & 741,90 & 0,00 \\
\hline
\end{tabular}

Источник: рассчитано авторами.

Сравнивая ситуацию с распределением господдержки в двух странах (табл. 2), нетрудно заметить, что в России больший акцент делается на прямую поддержку. В отличие от Республики Беларусь в России все виды культур, а также мясо и молоко имеют прямую поддержку. При этом она существенно выше и часто оказывается посредством ценовой поддержки. Так, по сахару и молоку прямая поддержка в 3 раза выше, чем по аналогичной продукции в Республике Беларусь.

\section{Таблииза 2}

Господдержка в России в 2011 г. долл./ 1 т произведенной продукции

\begin{tabular}{|l|l|l|l|}
\hline $\begin{array}{l}\text { Наименование } \\
\text { продукции }\end{array}$ & $\begin{array}{l}\text { Группа 1 } \\
\text { (общие меры) }\end{array}$ & $\begin{array}{l}\text { Группа 2 } \\
\text { (факторы производства) }\end{array}$ & $\begin{array}{l}\text { Группа 3 } \\
\text { (прямая поддержка) }\end{array}$ \\
\hline Пшеница & 7,4 & 27,7 & 14,4 \\
\hline Прочее зерно & 7,2 & 26,2 & 14 \\
\hline Масличные & 16,3 & 12,3 & 31,5 \\
\hline Сахар & 18,5 & 1,7 & 35,7 \\
\hline Овощи & 14,9 & 0,4 & 28,2 \\
\hline Картофель & 14,9 & 0,5 & 28,2 \\
\hline Фрукты & 39 & 0,4 & 12,5 \\
\hline Молоко & 16,1 & 16,3 & 33,7 \\
\hline Говядина & 72,3 & 115,1 & 150,4 \\
\hline Свинина & 94 & 11,5 & 196,8 \\
\hline Мясо птицы & 71,5 & 10 & 149,3 \\
\hline
\end{tabular}

Источник: рассчитано авторами. 
Однако общие меры поддержки в Республики Беларусь в целом выше, чем в России. Наиболее значительные средства направлены на поддержку мясного сектора. Аналогичная ситуация при сравнении поддержки факторов производства. Расчеты показали, что субсидирование факторов производства в подотраслях сельского хозяйства на единицу произведенной продукции в Республике Беларусь значительно больше: в 5 раз по говядине, в 10 раз по молоку, в 30 раз по свинине и в 70 раз по мясу птицы.

В то же время если сравнивать господдержку в России относительно цен производителей, то в табл. 3 нетрудно заметить, что цены на зерно компенсируются за счет господдержки на 30\% (в Республике Беларусь - не более 5\%), (табл. 4) - наибольший показатель среди всех видов продукции. Значительные компенсации получают производители говядины и молока - 19 и 16,7\%, поскольку эти сектора в России взаимосвязаны на 90\% ${ }^{1}$. Наименьшая поддержка относительно фермерской цены идет на овощи и фрукты - менее 6\%.

\section{Таблица 3}

Соотношение поддержки и фермерской цены в России в 2011 г.

\begin{tabular}{|l|l|l|}
\hline $\begin{array}{l}\text { Наименование } \\
\text { продукции }\end{array}$ & $\begin{array}{l}\text { Цены производителей, } \\
\text { долл./т }\end{array}$ & $\begin{array}{l}\text { Соотношение поддержки } \\
\text { к цене производителей, \% }\end{array}$ \\
\hline Пшеница & 156,9 & 31,5 \\
\hline Прочее зерно & 151,8 & 31,2 \\
\hline Масличные & 336,3 & 17,9 \\
\hline Сахар & 376,2 & 14,9 \\
\hline Овощи & 891,8 & 4,9 \\
\hline Картофель & 303,8 & 14,4 \\
\hline Фрукты & 989,6 & 5,2 \\
\hline Молоко & 395,7 & 16,7 \\
\hline Говядина & 1776,9 & 19,0 \\
\hline Свинина & 2328,3 & 13,0 \\
\hline Мясо птицы & 1768,6 & 13,0 \\
\hline
\end{tabular}

Источник: рассчитано авторами.

Следует отметить, что в целом в России удельная господдержка сельского хозяйства меньше, чем в Республике Беларусь. Так, в Республике Беларусь государство компенсирует 56\% цены молока и $37,2 \%$ цены сахара. В России господдержка сахара и молока не превышает $17 \%$ цены производителя. По мясу господдержка в обеих странах сопоставима: в пределах 15-20\% цены производителя.

1 Так как фактически примерно 90\% поголовья крупного рогатого скота (КРС) прямо или косвенно имеют отношение к производству и говядины, и молока. Среди КРС России чисто мясные породы составляют около $10 \%$ всего поголовья. 
Господдержка производства картофеля в обеих странах не превышает 15\%. Производство масличных в России субсидируется на $18 \%$ цены, а в Республике Беларусь эти культуры вообще не поддерживаются.

\section{Таблица 4}

\section{Соотношение поддержки и фермерской цены в Республике} Беларусь в 2012 г.

\begin{tabular}{|l|l|l|}
\hline $\begin{array}{l}\text { Наименование } \\
\text { продукции }\end{array}$ & $\begin{array}{l}\text { Цены производителей } \\
\text { без субсидий, долл./т }\end{array}$ & $\begin{array}{l}\text { Соотношение величины поддержки к } \\
\text { цене производителей, \% }\end{array}$ \\
\hline Пшеница & 182 & 5,1 \\
\hline Прочее зерно & 172 & 2,1 \\
\hline Масличные & 1770 & 0,0 \\
\hline Сахар & 702 & 37,2 \\
\hline Овощи & 769 & 9,8 \\
\hline Картофель & 104 & 14,6 \\
\hline Фрукты & 778 & 9,7 \\
\hline Молоко & 345 & 56,8 \\
\hline Говядина & 4227 & 15,4 \\
\hline Свинина & 2749 & 14,4 \\
\hline Мясо птицы & 3733 & 22,7 \\
\hline
\end{tabular}

Источник: рассчитано авторами на основе данных Белстата.

Проанализировав специфику господдержки сельскохозяйственного производства в Республике Беларусь, можно оценить расчеты по модели нескольких сценариев (сц.) в случае ее сокращения на: 1) 20\%, 2) 30\% и 3) $50 \%$.

Дополнительно были применены еще два сценария:

- повышение цен на границе на 20\% (сц. 5);

- снижение цен на границе на 20\% (сц. 6).

Данные сценарии можно отнести к разряду «шоковых». Повышение цен на границе на 20\% (сц. 4) - это некоторое отражение того, что было в 2007-2008 гг., когда вследствие сокращения запасов зерна и спекуляций на товарных рынках в мировой экономике наблюдался резкий рост цен на пшеницу, масличные, сахар, молоко и мясо - так называемый мировой продовольственный кризис. Снижение цен на границе на 20\% (сц. 5) - также экспериментальный сценарий, отражающий гипотезу, что вновь открывшийся рынок будет заполнен дешевой продукцией.

В первом сценарии для каждого продукта величина всех трех видов субсидий сокращалась на 20\%, во втором - на 30 , в третьем - на 50\% соот- 
ветственно. Для четвертого и пятого сценариев размер субсидий не менялся. В них для каждого продукта была увеличена или уменьшена цена на границе.

Одинаковое изменение господдержки по-разному влияет на различные продуктовые рынки, поскольку у каждого продукта есть своя эластичность спроса и предложения. Поэтому реакция спроса и предложения на более дешевые продукты постоянного потребления (товары Гиффена - картофель, хлеб) и более дорогие продукты (фрукты, мясо) будет разной, что можно заметить при анализе результатов расчетов.

Кроме того, в модель была заложена следующая идея, подтверждаемая нашими расчетами. Вследствие того, что в зависимости от вида продукции субсидии имеют разное влияние на фермерскую цену, результаты сокращения субсидий будут по-разному отражаться на производстве и ценах. Логично представить, что сокращение господдержки на $20 \%$ для производителей мяса, птицы и зерна будут иметь несимметричные последствия, потому что субсидии для производителей мяса птицы составляют 22,7\% цены, а для производителей зерна $-2-5 \%$. Поэтому анализ результатов представлен в виде величины отклонений от базового года в процентах. Помимо этого будут представлены сальдо внешней торговли в тоннах по видам продукции. Наконец, далее будет показано, как при различных сценариях изменяются общее производство продукции, доходы фермеров и выгода потребителей.

Расчеты показали, что по большинству продуктов снижение господдержки на 20, 30 и 50\% имеет примерно одинаковое влияние. Это можно объяснить низкой эластичностью предложения и спроса на сельхозпродукцию, полученных при калибровке модели. Кроме того, шаг прогноза (временной интервал) составляет один год, а за столь малый период сложно что-то поменять в такой отрасли, как сельское хозяйство, имеющее длинные циклы производства. Фермеры не могут слишком быстро реагировать на изменение «правил игры», в том числе таких, как госрегулирование.

Если говорить в целом о внешней торговле, то по большинству видов продукции сокращение господдержки незначительно влияет на торговое сальдо, и Беларусь остается нетто-экспортером продовольствия. Наши расчеты также показывают, что система гораздо острее реагирует на изменение цены, нежели на снижение господдержки - это будет видно по результатам расчетов по четвертому и пятому сценариям.

Анализ результатов сокращения господдержки показал, что независимо от снижения субсидий на 20, 30 или 50\% рынок пшеницы реагирует почти одинаково, т.е. объемы производства, потребления и цены меняются несущественно. 


\section{Таблица 5}

\section{Отклонения от базового года по пшенице, \%}

\begin{tabular}{|l|l|l|l|l|l|}
\hline \multirow{2}{*}{ Показатель } & \multicolumn{5}{|c|}{ Сценарий } \\
\cline { 2 - 7 } & $\mathbf{1}$ & $\mathbf{2}$ & $\mathbf{3}$ & $\mathbf{4}$ & $\mathbf{5}$ \\
\hline Производство & 0,2 & 0,2 & 0,2 & 4,3 & $-4,9$ \\
\hline Посевы пшеницы & 0,2 & 0,2 & 0,2 & 4,3 & $-4,9$ \\
\hline Импорт & $-2,5$ & $-2,5$ & $-2,7$ & $-12,2$ & 21,1 \\
\hline Экспорт & 0,8 & 0,8 & 0,8 & 8,6 & $-10,2$ \\
\hline Потребление & 0,2 & 0,3 & 0,2 & 1,1 & 0,8 \\
\hline Цена производителя с учетом субсидий & $-4,8$ & $-4,8$ & $-4,9$ & 28,2 & $-30,9$ \\
\hline Потребительская цена & $-0,2$ & $-0,2$ & $-0,2$ & 6,3 & $-5,4$ \\
\hline Сальдо (экспорт-импорт), тыс. т & $-191,3$ & $-191,7$ & $-190,2$ & $-114,5$ & $-342,3$ \\
\hline
\end{tabular}

Источник: рассчитано авторами по модели EPACIS.

В результате сокращения господдержки (сц. 1-3) производство пшеницы существенно не изменится - увеличится на $0,2 \%$. Отчасти это связано с тем, что доля субсидий в цене производителей пшеницы Республики Беларусь не превышает 5\% - достаточно низкий показатель, например, по сравнению с господдержкой молочной или сахарной подотраслей (57 и 37\%). Тем не менее цена производителей снизится почти на 5\%. Потребительские цены сократятся незначительно (на $0,2 \%$ ).

Уменьшение господдержки незначительно повлияет на внешнеторговые потоки: импорт снизится на 2,5\%, а экспорт вырастет на 0,8\%. По пшенице Беларусь остается нетто-импортером по всем пяти сценариям, поскольку граничит с Россией, которая поставляет ей большую часть зерна в достаточных количествах, хорошего качества и по сравнительно дешевой цене.

Рынок пшеницы будет более чувствительно реагировать на рост цены на границе на 20\% (сц. 4). Это приведет к росту цены производителей почти на $30 \%$ и соответственно будет стимулировать производство - увеличение валовых сборов на 4,3\%. Несмотря на рост потребительских цен на $6 \%$, спрос также увеличится на $1 \%$. Сальдо сократится за счет наращивания экспорта, но все равно останется отрицательным: $-114,5$ тыс. т.

Сценарий резкого снижения мировых цен на 20\% (сц. 5) будет способствовать росту импорта на 20\%, сокращению внутреннего производства пшеницы на 5\%, а также снижению цены производителей на $30 \%$. А отрицательное же сальдо торговли увеличится почти в 1,5 раза - до 342,3 тыс. т.

Расчеты по сокращению господдержки (сц. 1-3) показывают индифферентность реакции системы показателей прочего зерна (табл. 6). 


\section{Таблица 6}

\section{Отклонения от базового года по прочему зерну, \%}

\begin{tabular}{|l|l|l|l|l|l|}
\hline \multirow{2}{*}{ Показатель } & \multicolumn{5}{|c|}{ Сценарий } \\
\cline { 2 - 7 } & $\mathbf{1}$ & $\mathbf{2}$ & $\mathbf{3}$ & $\mathbf{4}$ & $\mathbf{5}$ \\
\hline Производство & $-0,1$ & $-0,1$ & $-0,1$ & 2,5 & $-3,2$ \\
\hline Посевы прочего зерна & $-0,1$ & $-0,1$ & $-0,1$ & 2,5 & $-3,2$ \\
\hline Импорт & $-8,0$ & $-7,9$ & $-8,2$ & $-10,0$ & 8,0 \\
\hline Экспорт & 1,8 & 1,7 & 1,8 & 5,5 & $-5,5$ \\
\hline Потребление & 0,3 & 0,3 & 0,3 & 1,0 & 0,6 \\
\hline Цена производителя с учетом субсидий & $-5,0$ & $-5,0$ & $-5,1$ & 33,9 & $-33,8$ \\
\hline Потребительская цена & $-0,6$ & $-0,6$ & $-0,6$ & 5,9 & $-5,4$ \\
\hline Сальдо (экспорт-импорт), тыс. т & 18,3 & 17,6 & 20,2 & 60,2 & $-146,2$ \\
\hline
\end{tabular}

Источник: рассчитано авторами по модели EPACIS.

Производство уменьшится на $0,1 \%$, цены производителей - на 5\%. Потребительская цена снизится на $0,6 \%$, что будет способствовать росту спроса на $0,3 \%$.

Наиболее чувствительная реакция у импорта прочего зерна: он возрастет на 8\%. Если в настоящее время Беларусь является нетто-импортером прочего зерна, то в результате сокращения господдержки она станет нетто-экспортером прочего зерна, поскольку модель показывает выгодность при таких условиях вывоза в большем количестве фуражного зерна ввиду его сравнительно низкой цены (141 долл./т против 182 долл./т).

Шоковый сценарий роста цен (сц. 4) демонстрирует положительные результаты для производителей прочего зерна в Республике Белорусь: внутренние цены вырастут на $34 \%$, валовые сборы - на 2,5\%, а импорт сократится на 10\%. И наоборот: снижение мировых цен (сц. 5) приведет к сокращению внутреннего производства и росту импорта. Несмотря на снижение потребительской цены в сц. 5 на 5\%, потребление вырастет лишь на 0,6\%, так как прочее зерно является товаром Гиффена, и спрос по цене на него неэластичен (0,2 против 0,8 по мясу или 0,5 по фруктам).

Поскольку производство масличных не субсидируется в республике, то и эффекта от сокращения господдержки здесь почти не наблюдается (табл. 7).

Если же рассмотреть сценарий роста цен (сц. 4), можно заметить небольшой рост внутреннего производства и значительное сокращение импорта (на 24,2\%). Поскольку Беларусь из масличных культур производит в основном рапс, то она по-прежнему остается нетто-импортером, в основном, вследствие импорта подсолнечного масла. 


\section{Таблица 7}

\section{Отклонения от базового года по растительному маслу, \%}

\begin{tabular}{|l|l|l|l|l|l|}
\hline \multirow{2}{*}{ Показатель } & \multicolumn{5}{|c|}{ Сценарий } \\
\cline { 2 - 7 } & $\mathbf{1}$ & $\mathbf{2}$ & $\mathbf{3}$ & $\mathbf{4}$ & $\mathbf{5}$ \\
\hline Производство & 1,7 & 1,7 & 1,7 & 3,5 & $-2,3$ \\
\hline Посевы масличных & 1,7 & 1,7 & 1,7 & 3,5 & $-2,3$ \\
\hline Импорт & $-2,1$ & $-2,1$ & $-2,2$ & $-24,2$ & 32,7 \\
\hline Экспорт & 2,0 & 1,9 & 2,0 & 6,9 & $-4,6$ \\
\hline Потребление & 0,4 & 0,4 & 0,4 & $-6,1$ & 9,0 \\
\hline Цена производителя с учетом субсидий & $-0,6$ & $-0,6$ & $-0,6$ & 35,1 & $-32,8$ \\
\hline Потребительская цена & $-0,4$ & $-0,4$ & $-0,5$ & 30,5 & $-29,0$ \\
\hline Сальдо (экспорт-импорт), тыс. т & $-30,7$ & $-30,8$ & $-30,7$ & $-6,3$ & $-67,3$ \\
\hline
\end{tabular}

Источник: рассчитано авторами по модели EPACIS.

В большей степени от сокращения господдержки пострадают производители сахара. Это связано с тем, что государство компенсирует им более 20\% затрат на производство сахарной свеклы (табл. 8).

\section{Таблица 8}

\section{Отклонения от базового года по сахару, \%}

\begin{tabular}{|l|l|l|l|l|l|}
\hline \multirow{2}{*}{ Показатель } & \multicolumn{5}{|c|}{ Сценарий } \\
\cline { 2 - 6 } & $\mathbf{1}$ & $\mathbf{2}$ & $\mathbf{3}$ & $\mathbf{4}$ & $\mathbf{5}$ \\
\hline Производство & $-2,0$ & $-2,0$ & $-2,0$ & $-0,2$ & $-5,0$ \\
\hline Посевы сахарной свеклы & $-2,0$ & $-2,0$ & $-2,0$ & $-0,2$ & $-5,0$ \\
\hline Импорт & 1,3 & 1,3 & 1,2 & $-8,7$ & 21,3 \\
\hline Экспорт & $-2,4$ & $-2,4$ & $-2,4$ & 2,2 & $-8,0$ \\
\hline Потребление & 0,3 & 0,3 & 0,3 & $-7,5$ & 13,2 \\
\hline Цена производителя с учетом субсидий & $-21,1$ & $-21,1$ & $-21,1$ & 8,6 & $-47,1$ \\
\hline Потребительская цена & 0,6 & 0,6 & 0,6 & 23,9 & $-26,7$ \\
\hline Сальдо (экспорт-импорт), тыс. т & 140,5 & 140,4 & 140,6 & 190,8 & 57,2 \\
\hline
\end{tabular}

Источник: рассчитано авторами по модели EPACIS.

В случае уменьшения субсидирования цена производителя может снизиться на $21,1 \%$, а производство - на $2 \%$. Сокращение господдержки повлияет на уменьшение спроса и рост импорта, но при этом Беларусь останется нетто-экспортером белого сахара.

Если же страна столкнется с резким ростом цен на сахар (сц. 4), производство сахара все равно сократится. Увеличение потребительских цен на 24\% при таком сценарии повлечет уменьшение потребления данного продукта на 7,5\%. Однако высокие цены на него будут стимулировать рост экспорта. 
Сценарий сокращения мировых цен на сахар (сц. 5) окажет болезненное влияние на производителей: цены снизятся почти на 50\%, производство сократится на 5\%, а импорт увеличится более чем на 20\%. В результате снижения потребительской цены на 27\% спрос увеличится на $13 \%$.

Результаты по овощам и картофелю представлены в табл. 9 и 10, по которым Республика Беларусь остается нетто-экспортером.

\section{Таблииа 9}

\section{Отклонения от базового года по овощам, \%}

\begin{tabular}{|l|l|l|l|l|l|}
\hline \multirow{2}{*}{ Показатель } & \multicolumn{5}{|c|}{ Сценарий } \\
\cline { 2 - 6 } & $\mathbf{1}$ & $\mathbf{2}$ & $\mathbf{3}$ & $\mathbf{4}$ & $\mathbf{5}$ \\
\hline Производство & $-0,8$ & $-0,8$ & $-0,8$ & $-0,9$ & $-0,9$ \\
\hline Посевы овощей & $-0,8$ & $-0,8$ & $-0,8$ & $-0,9$ & $-0,9$ \\
\hline Импорт & 2,1 & 2,1 & 2,0 & $-31,7$ & 77,1 \\
\hline Экспорт & $-0,6$ & $-0,6$ & $-0,6$ & 20,7 & $-22,7$ \\
\hline Потребление & 0,3 & 0,3 & 0,3 & 1,0 & 0,6 \\
\hline Цена производителя с учетом субсидий & $-6,9$ & $-6,8$ & $-6,9$ & $-3,2$ & $-9,5$ \\
\hline Потребительская цена & $-0,4$ & $-0,4$ & $-0,4$ & 1,7 & $-3,9$ \\
\hline Сальдо (экспорт-импорт), тыс. т & 7,9 & 7,9 & 7,9 & 99,0 & $-106,0$ \\
\hline
\end{tabular}

Источник: рассчитано авторами по модели EPACIS.

\section{Таблица 10}

\section{Отклонения от базового года по картофелю, \%}

\begin{tabular}{|l|l|l|l|l|l|}
\hline \multirow{2}{*}{ Показатель } & \multicolumn{5}{|c|}{ Сценарий } \\
\cline { 2 - 7 } & $\mathbf{1}$ & $\mathbf{2}$ & $\mathbf{3}$ & $\mathbf{4}$ & $\mathbf{5}$ \\
\hline Производство & $-1,2$ & $-1,2$ & $-1,2$ & $-2,9$ & 1,6 \\
\hline Посевы картофеля & $-1,2$ & $-1,2$ & $-1,2$ & $-2,9$ & 1,6 \\
\hline Импорт & $-1,7$ & $-1,6$ & $-2,0$ & $-18,8$ & $-46,0$ \\
\hline Экспорт & 0,1 & 0,0 & 0,1 & 9,4 & $-15,7$ \\
\hline Потребление & 0,1 & 0,1 & 0,1 & 0,4 & $-0,1$ \\
\hline Цена производителя с учетом субсидий & $-12,5$ & $-12,4$ & $-12,6$ & 5,6 & $-21,9$ \\
\hline Потребительская цена & $-1,1$ & $-1,0$ & $-1,2$ & 8,8 & $-5,7$ \\
\hline Сальдо (экспорт-импорт), тыс. т & 48,1 & 48,0 & 48,5 & 85,8 & 89,6 \\
\hline
\end{tabular}

Источник: рассчитано авторами по модели EPACIS. 
По фруктам сохраняется ситуация с нетто-импортом (табл. 11).

\section{Таблица 11}

\section{Отклонения от базового года по фруктам, \%}

\begin{tabular}{|l|l|l|l|l|l|}
\hline \multirow{2}{*}{ Показатель } & \multicolumn{5}{|c|}{ Сценарий } \\
\cline { 2 - 7 } & $\mathbf{1}$ & $\mathbf{2}$ & $\mathbf{3}$ & $\mathbf{4}$ & $\mathbf{5}$ \\
\hline Производство & $-0,1$ & $-0,1$ & $-0,1$ & 0,3 & $-1,6$ \\
\hline Многолетние насаждения & $-0,1$ & $-0,1$ & $-0,1$ & 0,3 & $-1,6$ \\
\hline Импорт & 3,1 & 3,1 & 3,1 & $-11,9$ & 23,4 \\
\hline Экспорт & 0,0 & 0,0 & 0,0 & 3,9 & $-4,8$ \\
\hline Потребление & 1,5 & 1,5 & 1,5 & $-6,3$ & 10,9 \\
\hline Цена производителя с учетом субсидий & $-7,0$ & $-7,0$ & $-7,0$ & 19,7 & $-33,4$ \\
\hline Потребительская цена & $-0,8$ & $-0,8$ & $-0,8$ & 15,5 & $-16,5$ \\
\hline Сальдо (экспорт-импорт), тыс. т & $-417,0$ & $-417,1$ & $-417,0$ & $-334,0$ & $-523,3$ \\
\hline
\end{tabular}

Источник: рассчитано авторами по модели ЕPACIS.

Беларусь производит ежегодно 6 млн т молока, и более половины его в виде различных молочных продуктов идет на экспорт. Все рассмотренные сценарии показывают, что при любых вариантах страна останется нетто-экспортером молочных продуктов (табл. 12).

\section{Таблица 12}

\section{Отклонения от базового года по молоку, \%}

\begin{tabular}{|l|l|l|l|l|l|}
\hline \multirow{2}{*}{ Показатель } & \multicolumn{5}{|c|}{ Сценарий } \\
\cline { 2 - 7 } & $\mathbf{1}$ & $\mathbf{2}$ & $\mathbf{3}$ & $\mathbf{4}$ & $\mathbf{5}$ \\
\hline Производство & $-4,7$ & $-4,7$ & $-4,7$ & $-0,9$ & $-8,8$ \\
\hline Поголовье молочных коров & $-4,7$ & $-4,7$ & $-4,7$ & $-0,9$ & $-8,8$ \\
\hline Импорт & 12,5 & 12,6 & 12,1 & $-1,7$ & $-97,6$ \\
\hline Экспорт & $-5,9$ & $-5,9$ & $-5,9$ & $-0,8$ & $-17,0$ \\
\hline Потребление & $-0,2$ & $-0,2$ & $-0,3$ & $-1,1$ & 0,0 \\
\hline Цена производителя с учетом субсидий & $-28,4$ & $-28,4$ & $-28,4$ & 1,4 & $-49,3$ \\
\hline Потребительская цена & 1,5 & 1,5 & 1,5 & 10,6 & $-0,5$ \\
\hline Сальдо (экспорт-импорт), тыс. т & 3071,2 & 3070,2 & 3073,8 & 3358,2 & 2783,0 \\
\hline
\end{tabular}

Источник: рассчитано авторами по модели EPACIS.

Мощная поддержка со стороны государства помогает молочному производству развиваться. В цене производителей молока субсидии превышают $30 \%$. Поэтому в случае сокращения господдержки фермерская цена упадет 
на $28 \%$, что повлечет уменьшение производства молока на $4,7 \%$ и рост импорта на 12\%. Потребительская цена на молоко вырастет на 1,5\% и повлияет на небольшое уменьшение спроса на $0,2 \%$, что логично, поскольку в Республике Беларусь - высокий уровень потребления молока и молочных продуктов: более 320 кг на душу населения в год.

Результаты расчетов по четвертому сценарию резкого роста цен на $20 \%$ показывают сокращение и производства, и потребления молока в республике. Наиболее чувствителен рынок молока к возможному снижению цен на $20 \%$ (сц. 5). В случае реализации такого сценария цена производителя уменьшится в два раза, а производство сократится почти на 9\%. Низкие цены откроют дорогу импорту, который увеличится на 98\%.

Сценарии сокращения господдержки меньше всего отразятся на производстве говядины, поскольку здесь наиболее длительные циклы производства. Кроме того, близость такого большого рынка, как Россия, позволяет постоянно наращивать экспорт (табл. 13).

\section{Таблица 13}

\section{Отклонения от базового года по говядине, \%}

\begin{tabular}{|l|l|l|l|l|l|}
\hline \multirow{2}{*}{ Показатель } & \multicolumn{5}{|c|}{ Сценарий } \\
\cline { 2 - 6 } & $\mathbf{1}$ & $\mathbf{2}$ & $\mathbf{3}$ & $\mathbf{4}$ & $\mathbf{5}$ \\
\hline Производство & 0,0 & 0,0 & 0,0 & 2,5 & $-3,0$ \\
\hline Поголовье КРС на убой & 0,0 & 0,0 & 0,0 & 2,5 & $-3,0$ \\
\hline Импорт & 2,7 & 2,7 & 2,5 & $-34,4$ & $-29,9$ \\
\hline Экспорт & $-0,4$ & $-0,4$ & $-0,4$ & 9,2 & $-15,8$ \\
\hline Потребление & 0,5 & 0,6 & 0,5 & $-6,4$ & 7,8 \\
\hline Цена производителя с учетом субсидий & $-9,6$ & $-9,6$ & $-9,6$ & 19,6 & $-31,3$ \\
\hline Потребительская цена & 0,8 & 0,8 & 0,7 & 15,2 & $-8,2$ \\
\hline Сальдо (экспорт-импорт), тыс. т & 138,2 & 138,2 & 138,3 & 156,6 & 117,8 \\
\hline
\end{tabular}

Источник: рассчитано авторами по модели EPACIS.

Расчеты по первым трем сценариям показали, что если цена уменьшится на 9,6\%, производство не изменится. Импорт вырастет незначительно - до $3 \%$. Однако в случае резкого роста цен (сц. 4) цена может увеличиться до $20 \%$, а производство - до 3\%. Импорт сократится на $34 \%$, а экспорт вырастет на 9,2\%. Снижение мировых цен на $20 \%$ (сц. 5) может оказать негативное влияние на производителей говядины Республики Беларусь: цены снизятся на $30 \%$.

Из всех представленных рынков свинина наиболее чутко реагирует на изменение объемов господдержки (табл. 14). Например, при сокращении 
субсидий на 20\% (сц. 1) импорт увеличится на 5,4\%, а при двукратном уменьшении господдержки (сц. 3) импорт вырастет на 8\%. В обоих случаях ожидается рост спроса: на 1,6 и 2,3\%. Республика Беларусь остается неттоэкспортером по свинине.

\section{Таблица 14}

\section{Отклонения от базового года по свинине, \%}

\begin{tabular}{|l|l|l|l|l|l|}
\hline \multirow{2}{*}{ Показатель } & \multicolumn{5}{|c|}{ Сценарий } \\
\cline { 2 - 7 } & $\mathbf{1}$ & $\mathbf{2}$ & $\mathbf{3}$ & $\mathbf{4}$ & $\mathbf{5}$ \\
\hline Производство & $-0,8$ & $-0,7$ & $-0,9$ & $-0,2$ & 0,3 \\
\hline Поголовье свиней & $-0,8$ & $-0,7$ & $-0,9$ & $-0,2$ & 0,3 \\
\hline Импорт & 5,4 & 4,4 & 8,1 & $-15,8$ & $-29,2$ \\
\hline Экспорт & $-1,0$ & $-1,2$ & $-0,6$ & 5,0 & $-22,3$ \\
\hline Потребление & 1,6 & 1,4 & 2,3 & $-8,6$ & $-3,8$ \\
\hline Цена производителя с учетом субсидий & $-9,2$ & $-9,0$ & $-9,8$ & 22,3 & $-20,3$ \\
\hline Потребительская цена & $-0,3$ & 0,1 & $-1,2$ & 17,5 & 6,3 \\
\hline Сальдо (экспорт-импорт), тыс. т & 23,5 & 24,6 & 20,5 & 65,6 & 48,7 \\
\hline
\end{tabular}

Источник: рассчитано авторами по модели EPACIS.

Еще более чувствителен в плане экспорта-импорта рынок мяса птицы. При сокращении господдержки растет импорт, сокращается экспорт. Однако страна остается нетто-экспортером по мясу птицы (табл. 15).

\section{Таблица 15}

\section{Отклонения от базового года по мясу птицы, \%}

\begin{tabular}{|l|l|l|l|l|l|}
\hline \multirow{2}{*}{ Показатель } & \multicolumn{5}{|c|}{ Сценарий } \\
\cline { 2 - 6 } & $\mathbf{1}$ & $\mathbf{2}$ & $\mathbf{3}$ & $\mathbf{4}$ & $\mathbf{5}$ \\
\hline Производство & $-1,7$ & $-1,7$ & $-1,7$ & $-0,1$ & $-2,8$ \\
\hline Поголовье птицы & $-1,7$ & $-1,7$ & $-1,7$ & $-0,1$ & $-2,8$ \\
\hline Импорт & 12,0 & 12,2 & 11,5 & $-30,2$ & 20,5 \\
\hline Экспорт & $-5,4$ & $-5,5$ & $-5,3$ & 29,9 & $-48,6$ \\
\hline Потребление & $-0,3$ & $-0,3$ & $-0,4$ & $-9,8$ & 8,2 \\
\hline Цена производителя с учетом субсидий & $-12,5$ & $-12,5$ & $-12,5$ & 8,4 & $-24,4$ \\
\hline Потребительская цена & 2,0 & 2,1 & 2,0 & 17,9 & $-6,4$ \\
\hline Сальдо (экспорт-импорт), тыс. т & 78,4 & 78,3 & 78,5 & 104,8 & 55,8 \\
\hline
\end{tabular}


В заключение, можно сделать обобщение, справедливое для всех рынков. Сокращение господдержки приводит к уменьшению цены производителя и не создает дополнительных стимулов для производства, поэтому оно сокращается. Параллельно происходит увеличение импорта, поскольку есть необходимость удовлетворить спрос.

Снижение поддержки совершенно естественно в наибольшей степени влияет на продукцию с ее высоким уровнем. Вместе с тем производство говядины реагирует в наименьшей степени на сокращение поддержки при относительно высоком ее уровне. Более конкурентоспособные товары положительно реагируют на открытие рынка (картофель).

Вследствие того, что производство не растет или сокращается, уменьшается экспорт. В результате этих процессов доходы производителей также снижаются. По проведенным расчетам в случае снижения субсидирования на $20 \%$ сельхозпроизводители потеряют 6,5\% своих доходов, при уменьшении господдержки на $30 \%$ доходы снизятся на 10\%, а при 50\%-ном сокращении субсидий выручка фермеров уменьшится на 16\% (табл. 16).

Если представить, что система попадает в ситуацию роста цен на продовольствие, то здесь можно ожидать увеличения производства и сокращение импорта. В нашем случае, если мировые цены на все виды сельскохозяйственной продукции увеличатся в среднем на $20 \%$, это приведет к росту доходов производителей на 46\%. При этом расходы потребителей повысятся на 7\%.

\section{Таблица 16}

\section{Изменение финансово-экономического положения аграрного сектора Республики Беларусь в результате сценарных расчетов, млн долл.}

\begin{tabular}{|c|c|c|c|}
\hline Показатель & $\begin{array}{l}\text { Изменения } \\
\text { в благосостоянии } \\
\text { при резком росте } \\
\text { цен на границе } \\
\text { на } 20 \%\end{array}$ & $\begin{array}{l}\text { Изменения } \\
\text { в благосостоянии } \\
\text { при резком } \\
\text { снижении цен } \\
\text { на границе на 20\% }\end{array}$ & $\begin{array}{l}\text { Изменения } \\
\text { в благосостоянии } \\
\text { при снижении } \\
\text { всей } \\
\text { господдержки } \\
\text { на } 30 \%\end{array}$ \\
\hline $\begin{array}{l}\text { Изменение } \\
\text { чистого дохода } \\
\text { производителей, } \\
\text { в том числе: }\end{array}$ & 2926 & -1955 & -616 \\
\hline $\begin{array}{l}\text { изменение доходов } \\
\text { от производственной } \\
\text { деятельности }\end{array}$ & 2935 & -1831 & 74 \\
\hline $\begin{array}{l}\text { изменение } \\
\text { государственных } \\
\text { субсидий, }\end{array}$ & -9 & -123 & -690 \\
\hline
\end{tabular}


Таблииа 16 (окончание)

\begin{tabular}{|c|c|c|c|}
\hline Показатель & $\begin{array}{l}\text { Изменения } \\
\text { в благосостоянии } \\
\text { при резком росте } \\
\text { цен на границе } \\
\text { на } 20 \%\end{array}$ & $\begin{array}{l}\text { Изменения } \\
\text { в благосостоянии } \\
\text { при резком } \\
\text { снижении цен } \\
\text { на границе на } 20 \%\end{array}$ & $\begin{array}{l}\text { Изменения } \\
\text { в благосостоянии } \\
\text { при снижении } \\
\text { всей } \\
\text { господдержки } \\
\text { на } 30 \%\end{array}$ \\
\hline \multicolumn{4}{|l|}{ из них: } \\
\hline $\begin{array}{l}\text { изменение прямых } \\
\text { платежей }\end{array}$ & -1 & -5 & -34 \\
\hline $\begin{array}{l}\text { изменение субсидий } \\
\text { на ресурсы }\end{array}$ & -8 & -118 & -656 \\
\hline $\begin{array}{l}\text { изменение выплат } \\
\text { в рамках «зеленого } \\
\text { ящика» }\end{array}$ & 0 & 0 & 0 \\
\hline $\begin{array}{l}\text { изменение доходов } \\
\text { государства, } \\
\text { в том числе }\end{array}$ & -56 & 102 & 766 \\
\hline $\begin{array}{l}\text { изменение доходов } \\
\text { от импортных } \\
\text { сборов }\end{array}$ & -75 & -31 & -16 \\
\hline $\begin{array}{l}\text { изменение доходов } \\
\text { от экспортных } \\
\text { сборов }\end{array}$ & 9 & -7 & 0 \\
\hline $\begin{array}{l}\text { изменение } \\
\text { государственных } \\
\text { субсидий } \\
\text { н, } \\
\text { из них: }\end{array}$ & 10 & 140 & 782 \\
\hline $\begin{array}{l}\text { изменение прямых } \\
\text { платежей }\end{array}$ & 1 & 5 & 34 \\
\hline $\begin{array}{l}\text { изменение субсидий } \\
\text { на ресурсы }\end{array}$ & 8 & 118 & 656 \\
\hline $\begin{array}{l}\text { изменение выплат } \\
\text { в рамках «зеленого } \\
\text { ящика» }\end{array}$ & 1 & 17 & 92 \\
\hline $\begin{array}{l}\text { Изменение } \\
\text { благосостояния } \\
\text { потребителей }\end{array}$ & -1350 & 1342 & 355 \\
\hline
\end{tabular}

Источник: рассчитано авторами.

При обратном сценарии: цены уменьшаются на 20\% - увеличивается импорт в страну продуктов с низкими ценами, производители сокращают производство и могут потерять до $31 \%$ доходов. При этом потребители будут платить за продукты питания на 7\% меньше обычного. 
Kiselev S., Strokov A., Belugin A. ${ }^{1}$

Evaluation of possible consequences of Republic Belarus accession to WTO:

\section{scenarios for agriculture}

The paper analyzes the effects of possible accession of the Belarus Republic to WTO. The estimates are obtained using the EPACIS econometric model and include data on agriculture and consumer markets. Consequences of reduction of state support in agriculture are presented.

Key words: Belarus, agriculture, WTO, EPACIS, econometric modeling.

1 Kiselev Sergey Victorovich - the Head of Agricultural Economics Board in Economic Faculty of Lomonosov Moscow State University, Doctor of Science, professor.

Strokov Anton Sergeevich - the Head of Economics Department in Eurasian Center for Food Security of Lomonosov Moscow State University, Ph.D.

Belugin Alexey Yurievich - researcher in Economics Department in Eurasian Center for Food Security of Lomonosov Moscow State University. 